\title{
Trends in Fine Particle Concentration and Chemical Composition in Southern California
}

\author{
Christos S. Christoforou, Lynn G. Salmon, Michael P. Hannigan, Paul A. Solomon, and Glen R. Cass \\ Environmental Engineering Science Department, California Institute of Technology, Pasadena, California
}

\begin{abstract}
Airborne fine particle mass concentrations in Southern California have declined in recent years. Trends in sulfate and elemental carbon (EC) particle concentrations over the period 1982-1993 are consistent with this overall improvement in air quality and help to confirm some of the reasons for the changes that are seen. Fine particle sulfate concentrations have declined as a strict sulfur oxides $\left(\mathrm{SO}_{\mathrm{x}}\right.$ ) emission control program adopted in 1978 was implemented over time. Fine particle elemental (black) carbon concentrations have declined over a period when newer diesel engines and improved diesel fuels save been introduced into the vehicle fleet. Organic aerosol concentrations have not declined as rapidly as the EC particle concentrations, despitethe fact that catalyst-equipped cars having lower particle emission rates were introduced into the vehiclefleet alongside the diesel en gineimprovements mentioned above. This situation is consistent with the growth in population and vehicle miles traveled in the air basin over time. Fine particle ammonium nitrate in the Los Angeles area atmosphere contributes more than half of the fine aerosol mass concentration on the highest concentration days of the year, emphasizing both the need for accurate aerosol nitrate measurements and the likely importance of deliberate control of aerosol nitrate as a part of any serious further fine particle control program for the Los Angeles area.
\end{abstract}

\section{IMPLICATIONS}

A National Ambient Air Quality Standard for fine particles smaller than $2.5 \mu \mathrm{m}$ in diameter $\left(\mathrm{PM}_{2.5}\right)$ has been proposed recently by the U.S. Environmental Protection Agency. As fine particles have not previously been subject to regulation, data on $\mathrm{PM}_{2.5}$ concentrations and chemical composition in cities are rare, leading to many questions about how fine particle concentrations behave over time. A strategy for monitoring the changes that occur over time in chemically distinct subtractions of the $\mathrm{PM}_{2.5}$ complex is illustrated in the present paper, based on data collected in Southern California since 1982.

\section{INTRODUCTION}

Airborne fine particles smaller than approximately 2.5$\mu \mathrm{m}$ diameter $\left(\mathrm{PM}_{2.5}\right)$ are largely responsible for the visibility deterioration seen both in urban areas like Los Angeles and Denver, as well as in national parks and wilderness areas..$^{1-6}$ Recent epidemiological studies al so find an association between fineparticle concentrations and increased human health effects. ${ }^{7-9}$ For these reasons, the U.S. Environmental Protection Agency (EPA) recently has proposed a National Ambient Air Quality Standard for $\mathrm{PM}_{2.5}{ }^{10}$

Fineparticle composition and concentration havenot been monitored routinely in urban areas on a national level in the United States. As a result, relatively little is known about trends in fine particle concentrations and composition over time in cities. The Los Angeles metropolitan area is an exception, for it has been studied extensively. ${ }^{11-15}$

During three 1-year periods since 1982, fine particle concentration and complete chemical speciation have been measured by our research group in Southern California. To date, only the 1982 data and a fraction of the 1993 data have been published. ${ }^{11,16}$ The sites over which the experiments have been carried out are shown in Figures 1a-1c for 1982, 1986, and 1993, respectively. Supplemental fine particle data also are available from dichotomous samplers that have been operated by the Cal ifornia Air Resources Board (CARB) at Long Beach, Azusa, and Rubidoux since 1989. Taken together, these data provide a long-term record extending back over the 14 years from 1982 to 1995.

Thepurposes of this paper are to describethese Southern California experiments, to present the previously unpublished fine particle composition data for 1986 and 1993, and to search for trends in the fine particle concentration and composition over the period 1982-1993 that may be associated with changes in emission control procedures known to have occurred over that decade.

\section{EXPERIMENTAL}

Experimentsconducted in 1982 are described in detail by Gray et al. ${ }^{11}$ The sampling system used is shown in Figure $2 a$. 


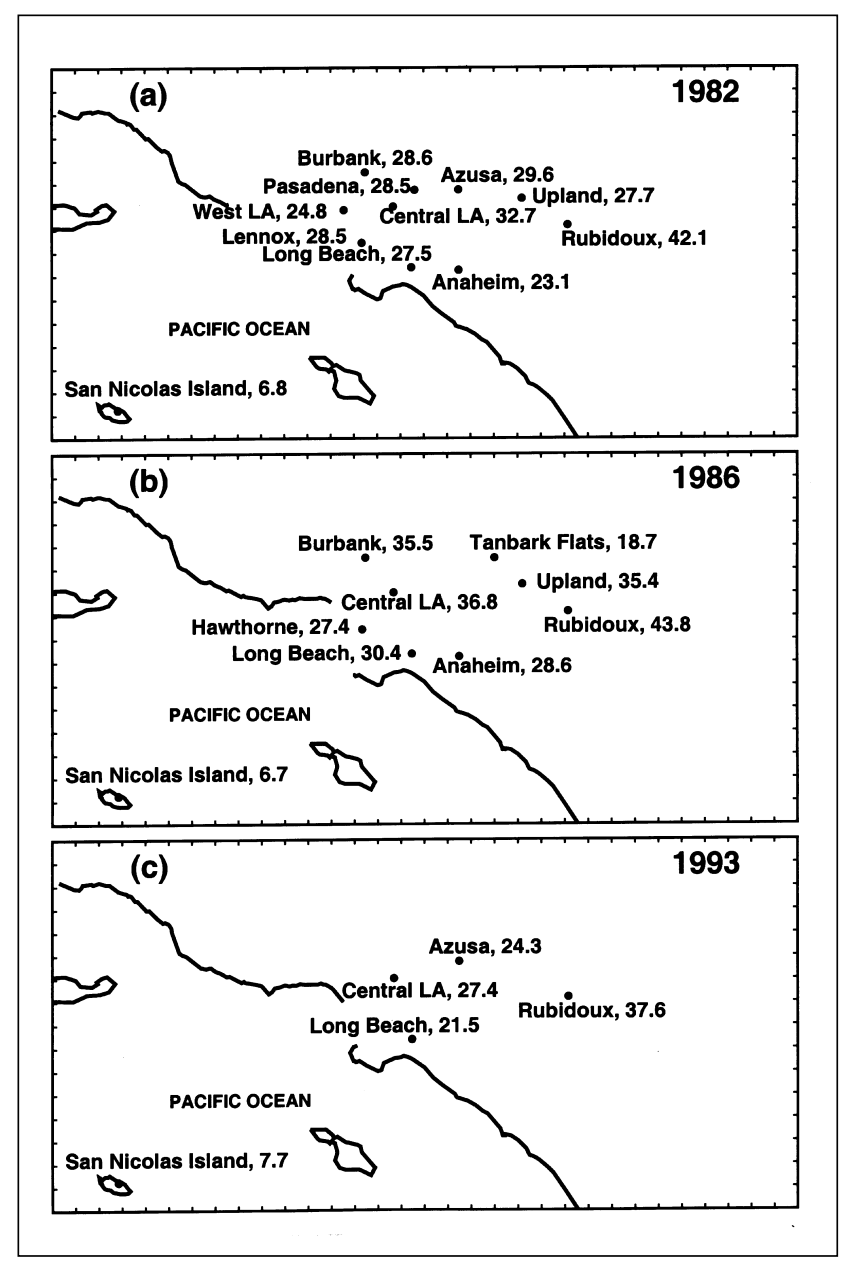

Figure 1. Ambient air monitoring sites in Southern California showing measured annual mean fine particle mass concentrations at each site. Units are $\mu \mathrm{g} \mathrm{m}^{-3}$.

Ambient air at a flow rate of $25.9 \mathrm{~L} \mathrm{~min}^{-1}$ is drawn through an AlHL-design cyclone separator designed to remove particles with aerodynamic diameter larger than $2.1 \mu \mathrm{m} .{ }^{17}$ The airflow containing the fine particles is then divided between four parallel filter holder assemblies, each having a filter substrate that is compatible with a particular chemical analysis procedure:

(1) Fine particle mass concentrations in the atmosphere are obtained by pre and postweighing 47$\mu$ m-diameter Teflon filters (Membrana 0.5- $\mu \mathrm{m}$ pore size) that are operated at a flow rate of $4.9 \mathrm{~L} \mathrm{~min}^{-1}$. The fine particulate matter collected on these filters is also analyzed for the concentration of 34 trace elements by $X$-ray fluorescence (XRF). ${ }^{18}$

(2) Samples taken for organic and elemental carbon determination (OC and EC, respectively) are collected on $47-\mu \mathrm{m}$-diameter quartz fiber filters (Pallflex 2500 QAO heat-treated at $600{ }^{\circ} \mathrm{C}$ for at least $2 \mathrm{hr}$ ) at a flow rate of $10 \mathrm{~L} \mathrm{~min}^{-1} . \mathrm{OC}$ and $\mathrm{EC}$ concentrationson thesefilters are measured by the methods of Huntzicker et al..$^{19}$ and Johnson et al..$^{20}$
(3) Thethird filter holder in Figure 2a contains a 47$\mu \mathrm{m}$-diameter Nuclepore filter (0.4- $\mu \mathrm{m}$ pore size) operated at $1 \mathrm{~L} \mathrm{~min}-1$ that was used for aerosol light absorption coefficient determination by the integrating plate technique. ${ }^{21}$ These filters also are analyzed for sulfates and nitrates by ion chromatography (IC), ${ }^{22}$ and for ammonium ion content by the phenol-hypochlorite method. ${ }^{23}$

(4) The remaining filter shown in Figure 2a is a quartz fiber filter operated at $10 \mathrm{~L} \mathrm{~min}^{-1}$ that is used for de termination of individual particulate organic compounds by gas chromatography/massspectrometry. ${ }^{24}$

Samples were collected for $24 \mathrm{hr}$ every sixth day during the entire year (1982) at 10 urban sites and al so at a background site on San Nicolas Island upwind of the city, as shown in Figure 1a. The combination of measurements made on the quartz fiber, Teflon, and Nuclepore filters allows a nearly complete material balance on the chemical composition of the fine particles to be obtained.

The sampler used during the 1986 experiments is diagrammed in Figure $2 \mathrm{~b}$. The concept and equipment are similar to the 1982 experiments except that the

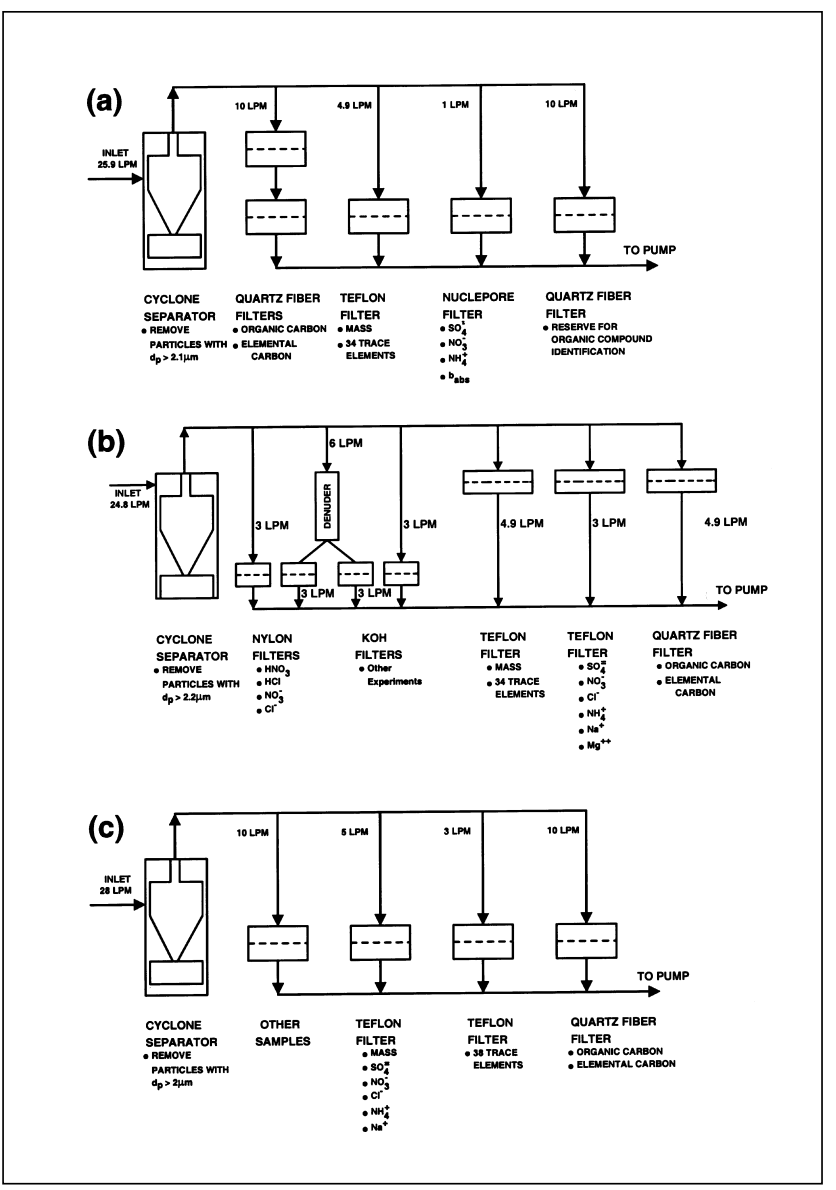

Figure 2. Schematic diagram of fine particle air pollutant samplers: (a) 1982, (b) 1986, and (c) 1993. 
denuder difference method for fine particle nitrate and nitric acid $\left(\mathrm{HNO}_{3}\right)$ measurement is employed in addition to collection of nitrate aerosol on Teflon filters. In the denuder difference method, a nylon filter $(1.0-\mu \mathrm{m}$ pore size, 47-mm diameter, Membrana Corp. and Gelman Sciences) located downstream of a Teflon-coated cyclone separator is used to collect fine particle nitrate plus $\mathrm{HNO}_{3}$ vapor, while a second nylon filter located below both the cyclone separator and a magnesium oxide-coated diffusion denuder (designed to quantitatively remove $\mathrm{HNO}_{3}$ ) collects only fine particle nitrate. Nylon filters act as a sink for $\mathrm{HNO}_{3}$ vapor and thus do not release $\mathrm{HNO}_{3}$ from decomposition of ammonium nitrate $\left(\mathrm{NH}_{4} \mathrm{NO}_{3}\right)$ during sampling. $\mathrm{HNO}_{3}$ concentration data are obtained from the difference between nitrate ions measured on these two nylon filters. As a consequence of this method, the fine particle nitrate concentration measurements obtained from the nylon filter that is located below the diffusion denuder do not suffer from large positive or negative nitrate measurement artifacts. ${ }^{25,26}$ Nylon filters are analyzed as described by Solomon et al. ${ }^{12,27,28}$

The quartz fiber filters used in 1986 were heat-treated Pallflex 2500 QAO filters (47-mm diameter), while the Teflon filters used were Gelman Teflo filters (47-mm diameter, $0.5-\mu \mathrm{m}$ pore size). Denuders were not employed for organics sampling in any of the years studied here, as organics denuder technology is still under development. Preliminary test samples taken employing an XAD-coated annular denuder ${ }^{29}$ ahead of a quartz fiber filter followed by a polyurethane foam cartridge show that the denuder prevents a positive artifact for organic aerosol averaging about $34 \%$ of the organics collected on an undenuded quartz fiber filter when sampling at Pasadena, CA, in the summer. This may also be accompanied by a negative artifact due to organic aerosol loss from the particle filter. Chemical analysis procedures for fine particles are identical to those for the coarse particulate $\left(\mathrm{PM}_{10}\right)$ aerosol samples described by Solomon et al. ${ }^{30}$ Samples were collected every sixth day for 24-hr sampling periods during the calendar year 1986, at seven urban sites shown in Figure 1b, plus the background site at San Nicolas Island, and also at a remote site downwind of the city in the San Gabriel M ountains at Tanbark Flats.

The sampling system used during the 1993 experiments is shown in Figure2c. The principal purpose of the 1993 experiments was to collect organic aerosol for use in mutagenicity testing and bioassay-directed chemical analysis. ${ }^{16,31}$ Thefine particlemass balance, which includes inorganic as well as organic chemical components reported in the present paper, is a byproduct of that study. ${ }^{32}$ Pretreated quartz fiber filters (47-mm diameter, Pallflex $2500 \mathrm{QAO}$, baked at $550^{\circ} \mathrm{C}$ for at least $6 \mathrm{hr}$ ) were used to collect samples destined for determination of atmospheric carbonaceous aerosol concentrations by thermal evolution and combustion analysis as described previously. Polytetrafluoroethylene (PTFE) filters (47-mm diameter, Gelman Teflo, $0.5-\mu \mathrm{m}$ pore size) were employed to acquire atmospheric particulate matter samples at theair flow rates shown in Figure 2c. These samples were used for mass concentration determination and for subsequent measurement of a wide variety of major and trace elements by $\mathrm{XRF}$ and water soluble anions and cation s by IC, colorimetry, and atomic absorption spectroscopy as described previously.

In 1993, the sampling sites chosen were Azusa, Long Beach, Central Los Angeles, Rubidoux, and San Nicolas Island. Sampling occurred every sixth day during 1993 and the samplers operated for $24 \mathrm{hr}$. In the present paper we will focus on the five sites that are common to all threeyearly experiments, or that are also included within the CARB low-volume dichotomous sampler network, namely, Long Beach, Central Los Angeles, Azusa, Rubidoux, and San Nicolas Island.

\section{RESULTS AND DISCUSSION}

Figure 1 shows the sites where the experiments were carried out during 1982, 1986, and 1993. Alongside each sampling station, the annual mean fine particle mass concentration is given in $\mu \mathrm{g} \mathrm{m}^{-3}$. The results are also summarized in Tables 1 and 2, which show the highest 24-hr average mass concentration as well as the annual average mass of airborne fine particles at the sites surveyed. Four sites have been studied in all three experiments: Long Beach, Central Los Angeles, Rubidoux, and San Nicolas Island. Average ai rborne fine particle mass concentrations at Long Beach, Central Los Angeles, and Rubidoux were lower in 1982 than in 1986, but have declined since, as indicated by the 1993 mass concentrations. For Long Beach, Central Los Angeles, and Rubidoux, 1993 airborne fine particle mass concentrations are 26,21 , and $12 \%$ lower, respectively, than the mean of the corresponding 1982 and 1986 annual average airborne fine particle mass concentrations. This downward trend is confirmed in Figure 3, which superimposes data from the CARB dichotomous sampler network, depicted in Figure 3 with a solid line, onto our data, which are indicated in Figure 3 with diamond symbols. Over the period from 1982 to 1995, based on 9 or 10 Caltech plus CARB annual average measurements per site, ordinary least-squares regression analysis of fine particle mass concentrations against time shows that the trend over time is $-0.95,-0.76$, and $-1.24 \mu \mathrm{g} \mathrm{m}^{-3}$ per year at Long Beach, Azusa, and Rubidoux, respectively. The trend is downward with greater than $95 \%$ confidence at Long Beach and Rubidoux, and with greater than $90 \%$ confidence at Azusa. Meanwhile, the background fine particle concentrationsupwind at San Nicolas Island have 
Table 1. Annual average fine particle mass concentrations $\left(\mu \mathrm{g} \mathrm{m}^{-3}\right)$.

\begin{tabular}{|c|c|c|c|c|c|c|c|c|c|c|}
\hline Site & $\begin{array}{l}\text { Fine } \\
\text { Mass }\end{array}$ & $\begin{array}{c}\text { Organic } \\
\text { Material }^{\mathrm{a}}\end{array}$ & $\begin{array}{c}\text { Elemental } \\
\text { Carbon }\end{array}$ & $\mathrm{SO}_{4}^{2}$ & $\mathrm{NO}_{3}^{-}$ & $\mathrm{Cl}^{-}$ & $\mathrm{NH}_{4}^{+}$ & $\mathrm{Na}^{+}$ & Crustal $^{b}$ & $\begin{array}{c}\text { Trace } \\
\text { Species }^{c}\end{array}$ \\
\hline \multicolumn{11}{|l|}{1982} \\
\hline Azusa & 29.6 & 8.0 & 3.3 & 5.8 & 2.8 & $-d$ & 2.9 & $-d$ & 3.4 & 1.8 \\
\hline Burbank & 28.6 & 12.2 & 5.0 & 6.2 & 1.4 & - & 2.4 & - & 3.3 & 2.0 \\
\hline Long Beach & 27.5 & 8.6 & 3.8 & 6.4 & 2.3 & - & 2.6 & - & 2.2 & 1.7 \\
\hline Lennox & 28.5 & 8.7 & 4.5 & 5.3 & 1.9 & - & 2.1 & - & 2.1 & 2.3 \\
\hline Pasadena & 28.5 & 9.5 & 4.0 & 6.0 & 2.1 & - & 2.7 & - & 2.1 & 1.7 \\
\hline West LA & 24.8 & 8.2 & 3.6 & 6.0 & 1.9 & - & 2.2 & - & 1.8 & 1.5 \\
\hline Central LA & 32.7 & 10.2 & 4.9 & 6.7 & 3.1 & - & 3.0 & - & 2.2 & 2.0 \\
\hline Upland & 27.7 & 7.5 & 3.1 & 5.5 & 4.0 & - & 3.0 & - & 1.9 & 1.4 \\
\hline Rubidoux & 42.1 & 7.3 & 3.0 & 5.9 & 10.5 & - & 5.1 & - & 3.0 & 1.4 \\
\hline Anaheim & 23.1 & 7.5 & 3.2 & 5.2 & 2.7 & - & 2.1 & - & 2.3 & 1.6 \\
\hline San Nicolas & 6.8 & 2.4 & 0.3 & 2.3 & 0.9 & - & 0.8 & - & 0.9 & 0.5 \\
\hline \multicolumn{11}{|l|}{1986} \\
\hline Burbank & 35.5 & 15.3 & 3.8 & 4.9 & 5.1 & 0.2 & 3.2 & 0.4 & 1.9 & 1.3 \\
\hline Long Beach & 30.4 & 12.1 & 3.0 & 5.2 & 4.6 & 0.3 & 3.0 & 0.5 & 1.6 & 1.2 \\
\hline Hawthorne & 27.4 & 10.6 & 2.7 & 5.3 & 3.4 & 0.2 & 2.6 & 0.5 & 1.7 & 1.3 \\
\hline Central LA & 36.8 & 15.6 & 3.9 & 5.3 & 5.4 & 0.2 & 3.3 & 0.4 & 1.8 & 1.4 \\
\hline Rubidoux & 43.8 & 11.1 & 2.5 & 4.6 & 13.4 & 0.3 & 5.9 & 0.3 & 2.5 & 1.1 \\
\hline Upland & 35.4 & 12 & 2.3 & 4.5 & 7.9 & 0.1 & 4.0 & 0.3 & 1.9 & 1.0 \\
\hline Anaheim & 28.6 & 11.3 & 2.5 & 4.8 & 5.1 & 0.2 & 3.0 & 0.4 & 2.2 & 1.1 \\
\hline Tanbark Flats & 18.7 & 8.1 & 1.0 & 3.6 & 1.6 & 0.1 & 1.7 & 0.2 & 1.2 & 0.9 \\
\hline San Nicolas & 6.7 & 2.4 & 0.1 & 1.6 & 0.7 & 0.9 & 0.7 & 0.7 & 0.6 & 0.8 \\
\hline \multicolumn{11}{|l|}{1993} \\
\hline Azusa & 24.3 & 13.1 & 1.3 & 3.8 & 3.2 & 0.0 & 1.9 & 0.3 & 2.3 & 0.6 \\
\hline Long Beach & 21.5 & 12.5 & 1.8 & 4.2 & 2.3 & 0.1 & 1.6 & 0.4 & 1.9 & 0.6 \\
\hline Central LA & 27.4 & 17.2 & 2.7 & 4.1 & 3.1 & 0.1 & 1.6 & 0.4 & 2.2 & 0.6 \\
\hline Rubidoux & 37.6 & 13.6 & 1.5 & 3.8 & 9.7 & 0.1 & 3.3 & 0.2 & 2.8 & 0.6 \\
\hline San Nicolas ${ }^{\mathrm{e}}$ & 7.7 & 2.2 & 0.1 & 2.1 & 0.4 & 0.5 & 0.3 & 0.5 & 0.4 & 0.2 \\
\hline
\end{tabular}

${ }^{\mathrm{a}}$ Organic carbon measured by the thermal/optical technique multiplied by 1.4 to compensate for $\mathrm{O}$ and $\mathrm{H}$ associated with organic matter.

${ }^{\mathrm{b}}$ Crustal material is estimated as the sum of $\mathrm{Al}, \mathrm{Si}, \mathrm{Fe}, \mathrm{Ti}, \mathrm{Mn}, \mathrm{Ca}$, and $\mathrm{K}$ oxides.

${ }^{\mathrm{C}}$ Trace species identified is equal to the sum of all species analyzed by XRF (except for S, Al, Si, Fe, Ti, Mn, Ca, K, Cl, and La) plus $\mathrm{Mg}^{+2}$ as determined by AAS.

${ }^{\mathrm{d}}$ Not measured in 1982.

${ }^{\mathrm{e}}$ Annual averages obtained from 18 measurements that represent 39 sampling events at other sites.

remained al most constant, averaging approximately $7 \mu \mathrm{g}$ $\mathrm{m}^{-3}$ over the period 1982-1993.

Thefine particlechemical composition at selected sites for each of the 3 years studied is shown in Figure 4 . The area of the pie charts is proportional to the annual average fine particle mass concentration. Organic compound concentrations given throughout this paper are estimated as 1.4 times the OC measured in order to account for $O$ and $\mathrm{H}$ associated with organic matter. Particle concentrations dervived from the earth's crust (e.g., soil dust; the dirt content of road dust) are estimated as the sum of $\mathrm{Al}, \mathrm{Si}, \mathrm{Fe}$, $\mathrm{Ti}, \mathrm{Mn}, \mathrm{Ca}$, and $\mathrm{K}$ converted to the equivalent molecular
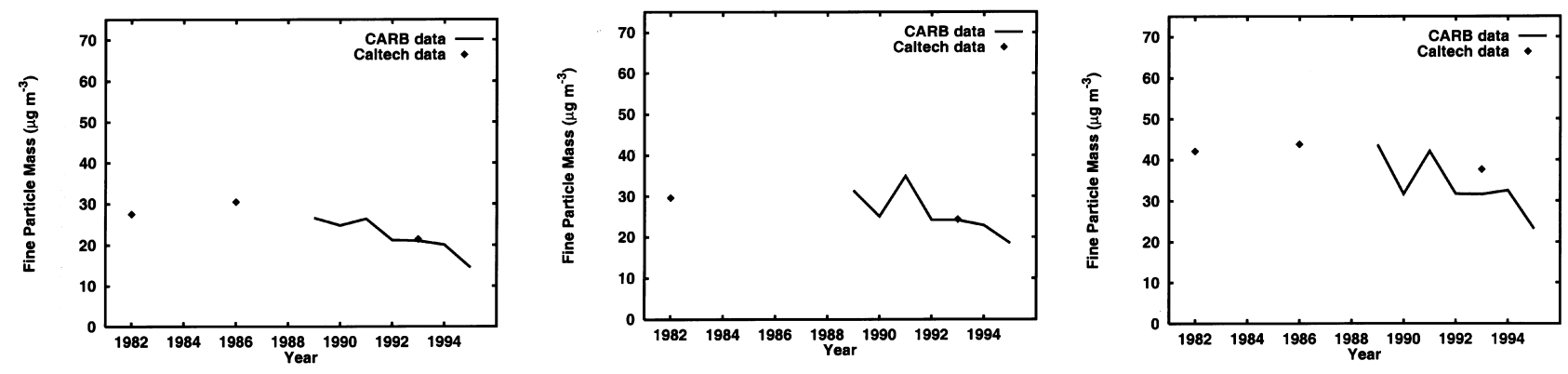

Figure 3. Annual average fine particle mass concentration over the period 1982-1995 at (a) Long Beach, (b) Azusa, and (c) Rubidoux. The solid line indicates data obtained from the CARB dichotomous sampler network while the solid symbols indicate data obtained by Caltech samplers. 
Table 2. Particle chemical composition on days with maximum 24-hr average fine particle mass concentrations $\left(\mu \mathrm{g} \mathrm{m}^{-3}\right)$.

\begin{tabular}{|c|c|c|c|c|c|c|c|c|c|c|c|}
\hline Site & Month & Fine Mass & $\begin{array}{l}\text { Organic } \\
\text { Material }^{\mathrm{a}}\end{array}$ & $\begin{array}{c}\text { Elemental } \\
\text { Carbon }\end{array}$ & $\mathrm{SO}_{4}^{-2}$ & $\mathrm{NO}_{3}^{-}$ & $\mathrm{Cl}^{-}$ & $\mathrm{NH}_{4}^{+}$ & $\mathrm{Na}^{+}$ & Crustal $^{b}$ & $\begin{array}{c}\text { Trace } \\
\text { Species }^{c}\end{array}$ \\
\hline \multicolumn{12}{|l|}{1982} \\
\hline Azusa & Feb & 99.1 & 13.4 & 8.7 & 10.8 & 17.4 & $-d$ & 9.4 & $-d$ & 4.1 & 3.1 \\
\hline Burbank & Dec & 85.4 & 28.4 & 17.6 & 17.6 & 1.6 & - & 7.3 & - & 7.0 & 4.8 \\
\hline Long Beach & Dec & 144.6 & 37.0 & 16.5 & 7.2 & 36.8 & - & 14.0 & - & 3.7 & 4.6 \\
\hline Lennox & Dec & 140.1 & 29.3 & 16.7 & 34.2 & 8.9 & - & 13.6 & - & 3.9 & 4.0 \\
\hline Pasadena & Dec & 97.0 & 18.3 & 9.2 & 21.3 & 12.4 & - & 12.8 & - & 3.3 & 3.2 \\
\hline West LA & Dec & 104.5 & 24.4 & 10.4 & 22.9 & 11.3 & - & 10.1 & - & 3.1 & 2.9 \\
\hline Central LA & Dec & 166.4 & 33.7 & 20.6 & 31.0 & 28.8 & - & 18.0 & - & 5.0 & 4.2 \\
\hline Upland & Dec & 86.5 & 10.2 & 6.7 & 14.8 & 24.9 & - & 12.4 & - & 2.7 & 1.8 \\
\hline Rubidoux & Feb & 142.4 & 12.0 & 6.9 & 6.8 & 30.0 & - & 10.5 & - & 3.7 & 3.2 \\
\hline Anaheim & Dec & 122.2 & 23.1 & 15.8 & 5.9 & 32.8 & - & 12.2 & - & 3.2 & 3.7 \\
\hline San Nicolas & May & 18.3 & 4.6 & 0.3 & 2.0 & 1.2 & - & 0.3 & - & 1.8 & 0.8 \\
\hline \multicolumn{12}{|l|}{1986} \\
\hline Burbank & Dec & 148.6 & 46.3 & 16.6 & 3.4 & 47.4 & 0.2 & 15.1 & 0.8 & 4.2 & 2.3 \\
\hline Long Beach & Dec & 101.1 & 22.6 & 8.3 & 4.5 & 37.9 & 0.7 & 12.6 & 0.5 & 2.6 & 2.0 \\
\hline Hawthorne & Dec & 110.0 & 24.4 & 8.6 & 6.7 & 41.3 & 0.9 & 13.8 & 0.5 & 3.4 & 1.7 \\
\hline Central LA & Dec & 138.8 & 40.4 & 14.4 & 4.5 & 53.8 & 0.4 & 16.0 & 0.5 & 4.0 & 2.0 \\
\hline Rubidoux & Oct & 242.6 & 36.0 & 5.9 & 18.4 & 93.0 & 0.3 & 38.2 & 0.2 & 3.5 & 1.4 \\
\hline Upland & Jan & 170.1 & 20.5 & 4.2 & 12.7 & 74.0 & 1.2 & 28.3 & 0.1 & 0.3 & 0.5 \\
\hline Anaheim & Mar & 100.4 & 26.0 & 3.9 & 17.4 & 11.9 & 0.2 & 10.4 & 0.5 & 2.6 & 2.7 \\
\hline Tanbark Flats & Oct & 57.5 & 23.3 & 3.2 & 7.5 & 7.3 & 0.0 & 5.0 & 0.1 & 2.1 & 1.7 \\
\hline San Nicolas & Oct & 27.0 & 1.7 & 0.3 & 3.1 & 0.2 & 0.0 & 1.1 & 0.2 & 0.7 & 0.5 \\
\hline \multicolumn{12}{|l|}{1993} \\
\hline Azusa & Oct & 95.0 & 14.9 & 0.8 & 9.2 & 28.7 & 0.2 & 12.8 & 0.2 & 2.8 & 1.1 \\
\hline Long Beach & Nov & 75.3 & 29.0 & 3.9 & 7.6 & 15.7 & 0.3 & 5.9 & 0.3 & 3.6 & 0.8 \\
\hline Central LA & Dec & 77.2 & 32.4 & 5.1 & 4.2 & 24.2 & 0.2 & 6.7 & 0.1 & 1.6 & 0.9 \\
\hline Rubidoux & Dec & 139.2 & 39.3 & 4.0 & 6.3 & 63.3 & 1.9 & 17.8 & 0.1 & 2.3 & 0.7 \\
\hline San Nicolas & Apr & 31.8 & 1.8 & 0.0 & 3.5 & 1.7 & 4.6 & 0.4 & 3.1 & 1.7 & 0.7 \\
\hline
\end{tabular}

${ }^{2}$ Organic carbon measured by the thermal/optical technique multiplied by 1.4 to compensate for $\mathrm{O}$ and $\mathrm{H}$ associated with organic matter.

${ }^{b}$ Crustal material is estimated as the sum of $\mathrm{Al}, \mathrm{Si}, \mathrm{Fe}, \mathrm{Ti}, \mathrm{Mn}, \mathrm{Ca}$, and $\mathrm{K}$ oxides.

${ }^{\mathrm{C}}$ Trace species identified is equal to the sum of all species analyzed by XRF (except for S, Al, Si, Fe, Ti, Mn, Ca, K, Cl and La) plus Mg ${ }^{+2}$ as determined by AAS.

dNot measured in 1982.

weight of their common oxides. A detailed account of the annual average chemical composition of the fine particulatematter at all sites in Figure 1 is given in Table 1 . At most sites, carbonaceous aerosols ( $E C+O C$ ), ammonium sulfate, and $\mathrm{NH}_{4} \mathrm{NO}_{3}$ arethemajor contributors to fine particlemass concentrations.

Figures 5-7 show the time series of the monthly average concentrations for six chemical species (EC, organic compounds, sulfate ion, nitrate ion, ammonium ion, and crustal oxides) in $\mu \mathrm{g} \mathrm{m}^{-3}$ over the three years of experiments at Long Beach, Central Los Angeles and Rubidoux, respectively. Primary particle concentrations, typified by black EC particles, show seasonal variations that are similar to those for $\mathrm{CO}$. High concentrations are observed during the stagnant winter months, while low concentrations are observed during the summer months, especially at Long Beach and Central Los Angeles. The land/sea breeze wind reversal also affects concentrations seasonally. In general, it is seen that EC concentrations have declined substantially over time as evidenced by the 1993 data when compared to the 1982 and 1986 data. EC concentrations in the Southern Cal ifornia area historically were dominated by diesel engine exhaust. ${ }^{33-35}$ Reductions in EC concentrations reflect improved diesel engine emission control. Traps to collect particulate matter, oxidation catalysts for reducing vapor-phase hydrocarbons as well as soluble particulate organics, creative and innovative engine designs, exhaust gas recirculation, and improved fuels are some of the methods introduced over the years since 1982 for controlling the emissions from new diesel engines. As a result, particulate matter emission s from new heavy-duty diesel engines have declined from circa 1 to $3 \mathrm{~g} \mathrm{~kW}^{-1} \mathrm{hr}^{-1}$ in the 1970 s to 0.1 to $0.3 \mathrm{~g} \mathrm{~kW}^{-1} \mathrm{hr}^{-1}$ in the $1990 \mathrm{~s}^{36}$

As these newer diesel engines have been introduced into the vehiclefleet, fleet averageemissions have declined. Measurements made in highway tunnels in the late 1970s show a fleet average, diesel truck particle mass emission rate of $870 \pm 160 \mathrm{mg} \mathrm{km}^{-1}$ of which $55 \%$ of the mass (478 $\mathrm{mg} \mathrm{km}^{-1}$ ) was EC. ${ }^{37}$ By 1993, measurements made in the Ft. McHenry Tunnel near Baltimore, MD, show a lower 


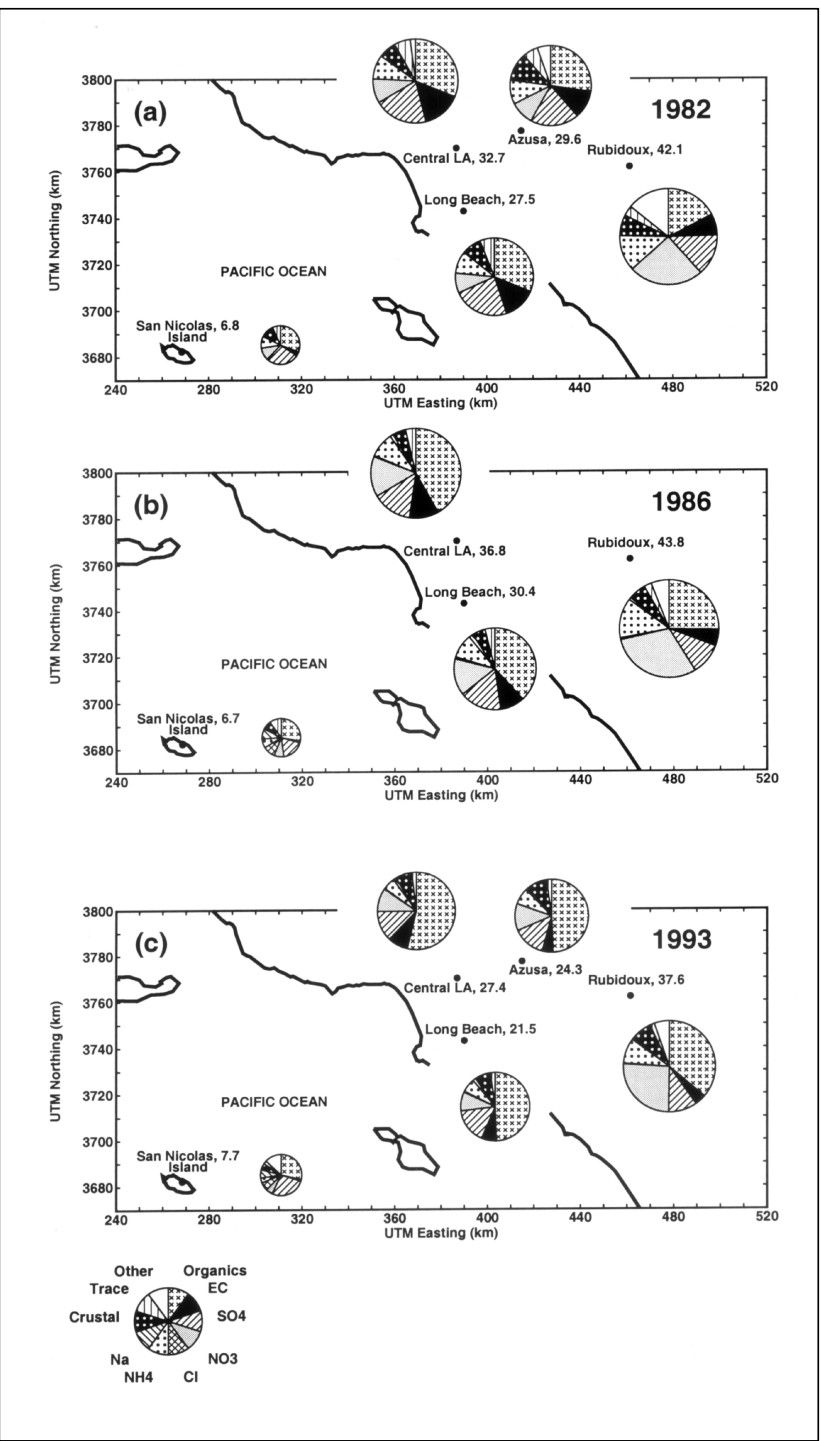

Figure 4. Material balance on annual average fine particle chemical composition for (a) 1982, (b) 1986, and (c) 1993, showing annual average fine particle mass concentrations in $\mu \mathrm{g} \mathrm{m}^{-3}$ at each monitoring site location. The area of the pie charts is proportional to the annual average fine particle mass concentration.

diesel truck fleet emission rate of $417 \mu \mathrm{g} \mathrm{km}{ }^{-1} .{ }^{38}$ Source tests of 1986 model diesel truck engines show that the massfraction EC in fine particleemissionshasalso declined to about $40.5 \%$ of total mass. ${ }^{39}$ Combining the 1993 tunnel study data with this lower fraction EC in diesel exhaust yields an estimated fleet EC emission rate of about $169 \mathrm{mg} \mathrm{km}^{-1}$, which is about $35 \%$ of the EC emission rate from the fleet in the late 1970s. This compares to an average decline of ambient EC concentrations at the four urban Los Angeles area sites studied in 1993 to $32 \%$ (range $29-40 \%$ ) of the EC concentrations measured in 1982. The reduced black carbon particle concentrations seen in the Los Angeles atmosphere over this period are consistent with the progressive addition of cleaner diesel engines to the vehicle fleet over time, as well as the use of cleaner-burning diesel fuels.

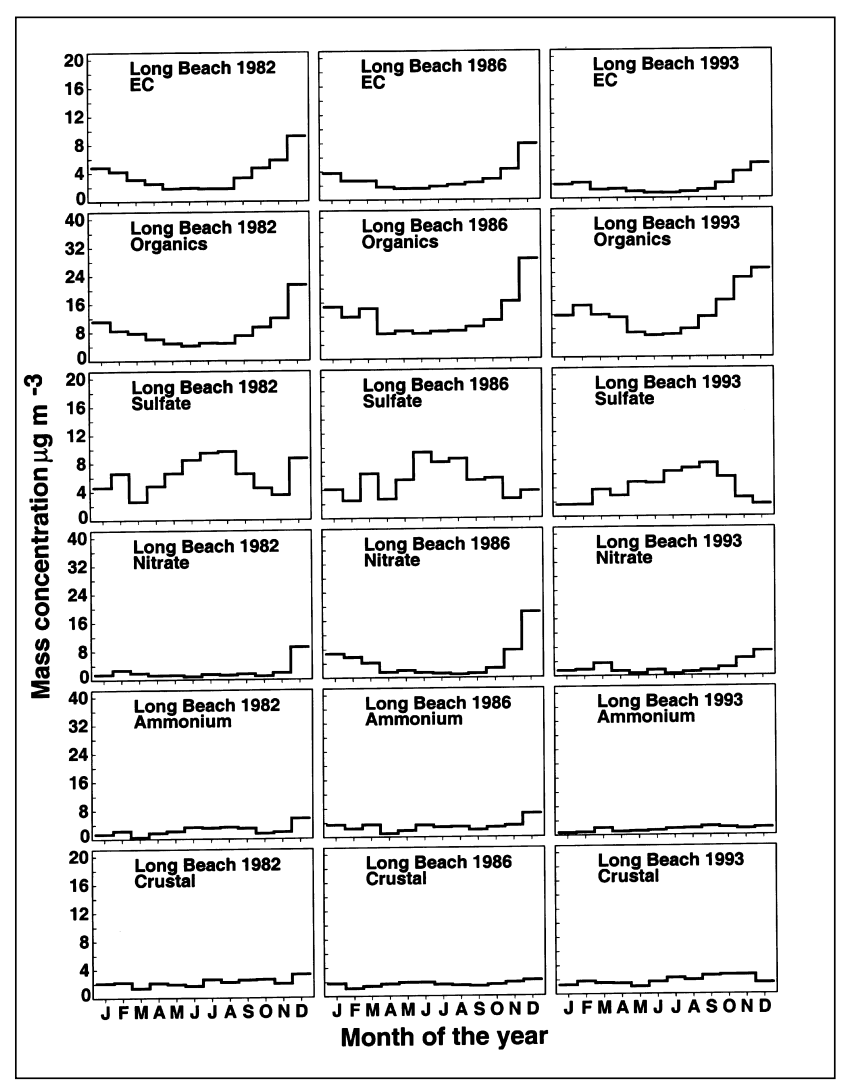

Figure 5. Monthly average concentrations for six fine particle chemical species at Long Beach during 1982, 1986, and 1993.

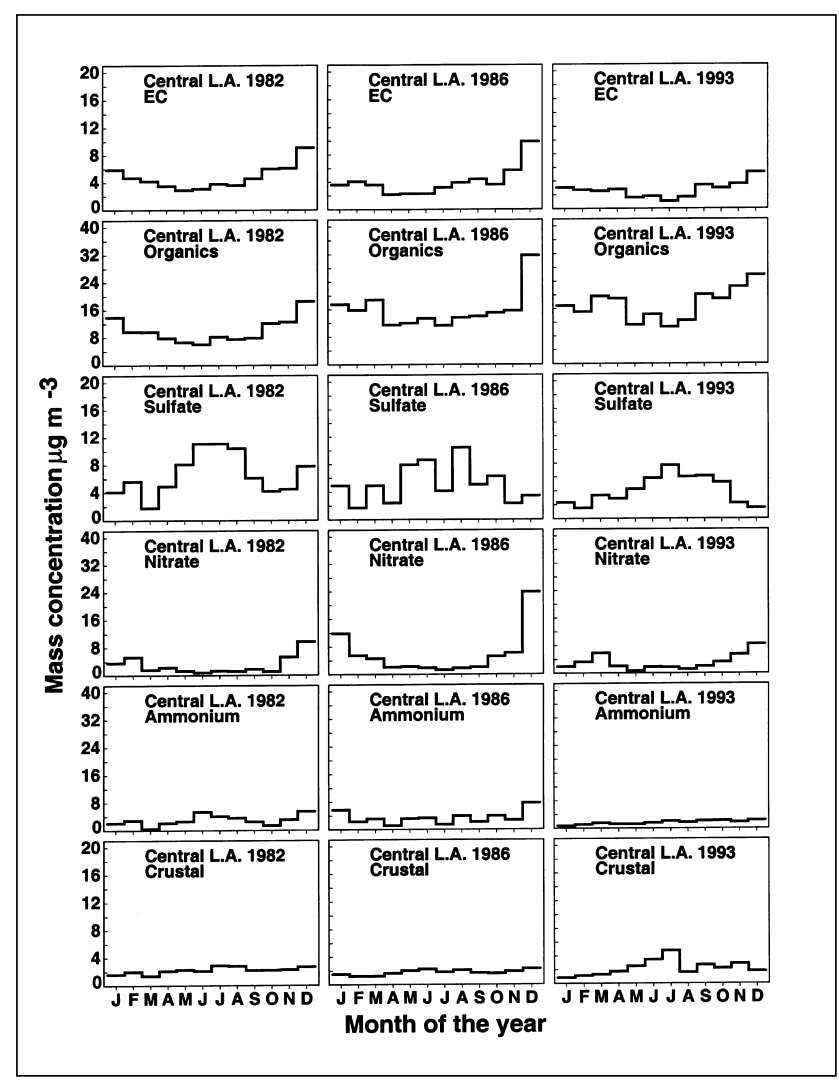

Figure 6. Monthly average concentrations for six fine particle chemical species at Central Los Angeles during 1982, 1986, and 1993. 


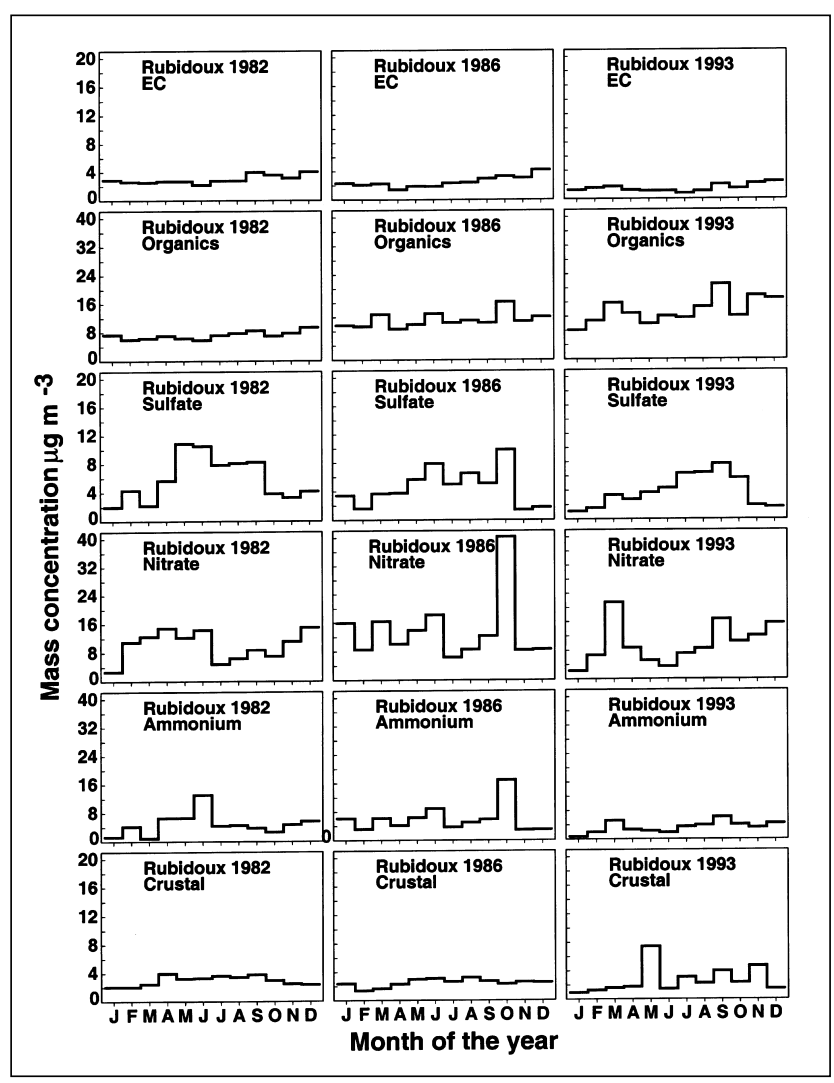

Figure 7. Monthly average concentrations for six fine particle chemical species at Rubidoux during 1982, 1986, and 1993.

Particulate organic compound concentrations follow a seasonal trend that is similar to EC. There is a strong seasonal variation with high concentrations in the winter and low concentrations in thesummer, especially at Long Beach and Central Los Angeles. That seasonal variation is not as pronounced as one moves further inland, at Rubidoux. Previous work by Gray and Cass, ${ }^{35}$ Hildemann et al., ${ }^{40}$ and Schauer et al. ${ }^{34}$ shows that the annual average fine particle organics concentration in the Los Angeles atmosphere is mostly dueto direct particleemissions from primary sources. For that reason, the organics data appear similar to the EC data in terms of seasonal variation. Organic aerosol concentrations have not declined over time in the same way as EC. In part, this situation is due to a competition between further penetration of catalyst-equipped vehicles into theautomobilefleet, which tends to lower organic aerosol emissions, versusincreases in population and vehiclemiles traveled over time, which tend to increaseemissions. M otor vehiclesource tests conducted on in-use Southern California automobiles by Hildemann et al. ${ }^{39}$ showed that the six noncatalystequipped automobiles tested while burning low-lead gasoline emitted $59.4 \mathrm{mg}$ of fine particles per $\mathrm{km}$ driven, $78.6 \%$ of which was composed of organic compounds, while the corresponding emissions from the seven catalyst-equipped autos tested were only $18.0 \mathrm{mg} \mathrm{km}^{-1}$, of which $60.1 \%$ consisted of organic compounds, and newer cars would be expected to be even cleaner. As more catalyst-equipped automobiles have replaced noncatalyst cars over time, primary organic aerosol emissions per vehicle mile traveled (VMT) have declined. Reductions in particulate organics emissions per VMT over time al so are due in part to reduced emissions from diesel engines, as explained previously.

However, between 1982 and 1993, VMT in the South Coast Air Basin increased by a factor of 1.58 (compare Gray ${ }^{41}$ to South Coast Air Qual ity Management District ${ }^{42}$ ). During this period, miles travel ed by noncatalyst vehicles dropped to approximately $3.5 \%$ of the VMT of the lightduty vehicle fleet in 1993, compared to approximately $28 \%$ of the light-duty VMT in 1982 . Applying the OC emissions data from Hildemann et al. ${ }^{39}$ discussed above, and considering both the growth in VMT and the shift in vehicle type between 1982 and 1993, one can calculate that air basin-wide, fine organic particulate matter emissions from the light-duty fleet in 1993 were probably about $92 \%$ of the values experienced in 1982 . When combined with the effect of population growth on primary organic aerosol sources that are not yet subject to control (e.g., emissions from food cooking, residential wood combustion, and paved road dust), it is not surprising that particulate organic compound concentrations in the atmosphere have not declined in the same way as EC concentrations have. Total particle mass emissions from gasoline-powered motor vehicles, of course, have declined substantially between the mid-1970s and 1993, as fine particle lead halide emissions and coarse particle emissions of all types have been greatly reduced through the use of unleaded gasoline and catalystequipped cars. The overall decline in total particle mass emissions from noncatalyst cars from circa $200 \mathrm{mg} \mathrm{km}^{-1}$ more than 20 years ago to be replaced by the roughly 18 $\mathrm{mg} \mathrm{km}^{-1}$ emitted from the in-use catalyst-equipped cars tested by Hildemann et al. ${ }^{39}$ is so large that it does outpace the increase in VMT and contributes to the general decline in particle mass concentrations over time, even if it does not necessarily bring down fine particle OC concentrations in more recent years.

Sulfateion concentrations follow a similar trend at the three sites examined closely in Figures 5-7, showing summertime peaks, with lower concentrations during the winter months. A progressive decline in sulfate concentrations is observed from 1982 to 1986 to 1993 . Sulfate concentrations arise from marine background aerosol plus urban primary sulfate particleemissions, as well as from atmospheric chemical reactionsthat oxidizesulfur dioxide $\left(\mathrm{SO}_{2}\right)$ to form sulfates. Sulfate peaks in the summertime are due to increased atmospheric $\mathrm{SO}_{2}$ oxidation at that time of year. ${ }^{43}$ The highest $\mathrm{SO}_{4}^{-2}$ concentration events in the Southern California atmosphere historically have been associated with $\mathrm{SO}_{2}$ oxidation in the liquid phase during coastal 
fogs. ${ }^{43,44}$ The concentrations of sulfates in the Southern California atmosphere have declined over theyears largely due to the imposition of strict controls both on $\mathrm{SO}_{2}$ emissions from industrial processes and on the sulfur content of fuels. In 1973, approximately 530 tons day ${ }^{-1}$ of total $\mathrm{SO}_{x}$ wereemitted in thegreater LosAngelesarea, and peak daily $\mathrm{SO}_{4}{ }^{-2}$ concentrations reached $73 \mu \mathrm{g} \mathrm{m}^{-3}$ at Central Los Angeles in that year. ${ }^{43}$ In 1978, a strict $\mathrm{SO}_{\mathrm{x}}$ emission control program was designed for the Los Angeles area that was specifically intended to abate the high sulfate concentration sexperienced during the 1970s. ${ }^{43-45}$ By $1990, \mathrm{SO}_{x}$ emissions had been reduced to 120 tons day $^{-1}$ in the South Coast Air Basin that surrounds Los Angeles. ${ }^{46}$ The corresponding peak 24-hr average fine particle sulfate concentrations measured during our experiments at Central Los Angeles have

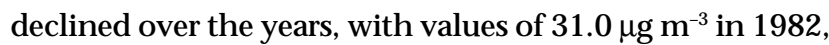
$17.6 \mu \mathrm{g} \mathrm{m}^{-3}$ in 1986 , and $12.5 \mu \mathrm{g} \mathrm{m}^{-3}$ during 1993. Beginning with total suspended particulate sulfate concentrations that averaged more than $14 \mu \mathrm{g} \mathrm{m}^{-3}$ during 1973, annual average fine particle sulfate concentrations at Central Los

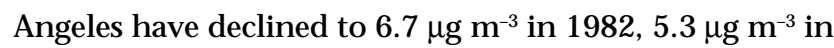

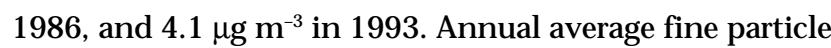
sulfate concentrations will continue to decline with the further reduction in local $\mathrm{SO}_{2}$ emissions that will accompany the recent introduction of lower sulfur gasoline, eventually approaching the $2.1 \mu \mathrm{g} \mathrm{m}^{-3}$ annual mean fineparticle $\mathrm{SO}_{4}^{-2}$ background concentration measured upwind of the city at San Nicolas Island as local $\mathrm{SO}_{2}$ emissions approach zero. $\mathrm{SO}_{\mathrm{x}}$ emission control obviously does lead to reduced particulate sulfate concentrations in Los Angeles.

Fine particle nitrate concentrations are high, and are seen to increase as one moves further inland, from Long Beach to Central Los Angeles to Rubidoux. At Long Beach and Central LosAngeles, thehighest nitrateconcentrations occur in thecooler winter months, whileat Rubidoux high nitrate concentrations can occur throughout the year. The causes and potential approaches to control of the high nitrate concentrations in Southern California, particularly at Rubidoux, are explained in great detail through photochemical modeling by Russell and Cass $^{47}$ and by Russell et al. ${ }^{48,49}$ Briefly, $\mathrm{HNO}_{3}$ vapor formed by oxidation of atmospheric nitrogen dioxide $\left(\mathrm{NO}_{2}\right)$ reacts with gaseous ammonia to produce $\mathrm{NH}_{4} \mathrm{NO}_{3}$ aerosol and with sea salt to produce sodium nitrate aerosol. Rubidoux encounters some of the highest $\mathrm{NH}_{4} \mathrm{NO}_{3}$ concentrations observed anywhere in the nation because it is both downwind of the major nitrogen oxides $\left(\mathrm{NO}_{\mathrm{x}}\right)$ emissions sources in the western portion of the Los Angeles basin, and also downwind of the concentrated ammonia sources created by agricultural and animal husbandry activities in Western Riverside and San Bernardino Counties (e.g., the Chino dairy area; farmlands where fertilizers are used, etc.) For a detai led account of ammonia emissions, see Russell and Cass. ${ }^{47}$ Average nitrate concentrations during 1986 exceeded those measured during either 1982 or 1993.

The concentrations of $\mathrm{NO}_{3}{ }^{-}$shown in Figures 4-7 are as measured on Teflon filters. Appel et al., ${ }^{25,50}$ Forrest et al., ${ }^{51}$ and Solomon et al. ${ }^{27}$ have shown that $\mathrm{HNO}_{3}$ measurements obtained by collection on a nylon filter located downstream of a Teflon filter (thetandem filter method) are higher than $\mathrm{HNO}_{3}$ measurements obtained using the denuder difference method shown in Figure 2b. The difference is in part due to the vaporization of $\mathrm{NH}_{4} \mathrm{NO}_{3}$ aerosol that is collected on the Teflon filter used in the tandem filter method. Such vaporization results in, among other things, a negativemeasurement artifact for particulate $\mathrm{NO}_{3}^{-}$. During the 1986 experiments, a denuder differencemethod (see Figure 2b) was used to measure the magnitude of this $\mathrm{NH}_{4} \mathrm{NO}_{3}$ loss. The results are shown in Figure 8. Figure 8a illustrates the fine particulate $\mathrm{NO}_{3}{ }^{-}$concentrations measured on a Teflon filter and the difference in $\mathrm{NO}_{3}{ }^{-}$measurements between that Teflon filter sample versus fine particulate $\mathrm{NO}_{3}{ }^{-}$measured on a nylon filter located below the denuder shown in Figure $2 \mathrm{~b}$. Since the nylon filters, if used correctly, are effectively a perfect sink for the nitrate content of $\mathrm{NH}_{4} \mathrm{NO}_{3}$, the difference in nitrate content between the Teflon versus nylon filter samples is a measure of the amount of $\mathrm{NH}_{4} \mathrm{NO}_{3}$ volatilized from the Teflon filter during sampling; the volatilized ammonia is not measured.

Figure $8 \mathrm{~b}$ depicts the percentage of the $\mathrm{NO}_{3}{ }_{3}^{-}$lost due to this partial vaporization of $\mathrm{NH}_{4} \mathrm{NO}_{3}$ aerosol, and it is seen that the losses are highest during the hotter part of the year, as expected for a process that is sensitive to thermal decomposition. As a result of this loss, fine particle mass measured on Teflon filters provides an underestimate of the true fine particle mass concentration in the atmosphere. Corrected fine particle mass will be defined here as equal to the sum of the reported fine particle mass as measured on a Teflon filter, plus the difference in the $\mathrm{NO}_{3}{ }^{-}$ion concentration measured on the nylon filter located below the denuder in Figure $2 b$, versus that collected on the Teflon filter shown in the same figure, multiplied by 1.29 under the approximation that a stoichiometrically equivalent amount of $\mathrm{NH}_{4}{ }^{+}$ion was lost along with the lost $\mathrm{NO}_{3}{ }^{-}$. The extent of this correction to the fine particle mass is shown in Figure 8c. During 1986, fine particle mass concentrations would have averaged 34.4, 42.5, and $50.7 \mu \mathrm{g} \mathrm{m}^{-3}$, respectively, at Long Beach, Central Los Angeles, and Rubidoux, once the correction for $\mathrm{NH}_{4} \mathrm{NO}_{3}$ evaporation during sampling has been taken into account, an increase of $13-16 \%$ above the mass concentration values measured on Teflon filters.

Figures 5-7 also depict the monthly average concentrations of ammonium ion at Long Beach, Central Los Angeles, and Rubidoux, respectively. Ammonium follows the same trend as nitrate plus sulfate, as expected, since $\mathrm{NH}_{4}{ }^{+}$is 


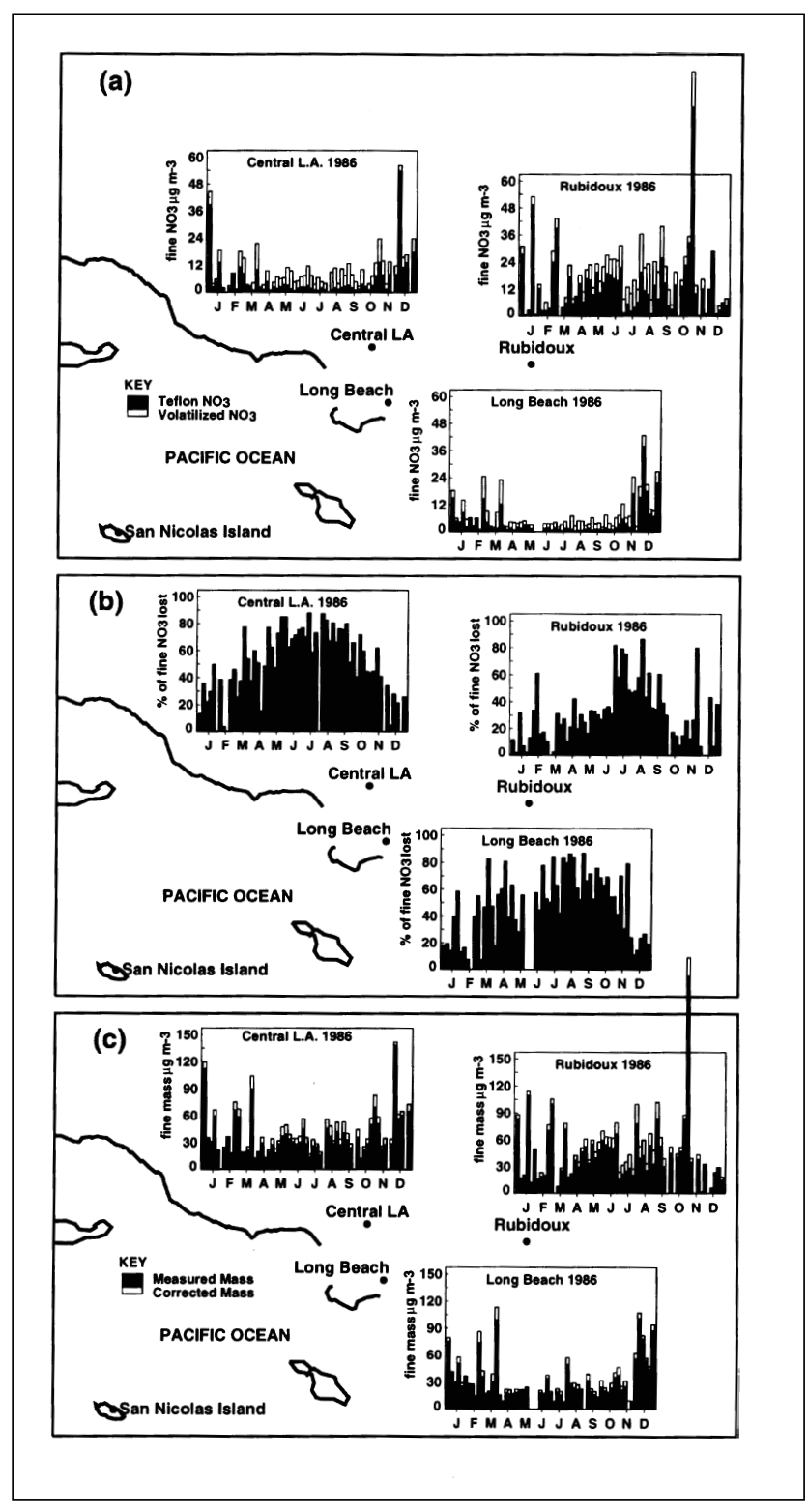

Figure 8. Twenty-four-hr average fine particle nitrate ion concentrations measured in 1986. (a) Nitrate ion collected on Teflon filters shown in black compared to actual fine particle nitrate ion concentration present as determined by denuder difference sampler (black plus white bars). The white bars indicate the quantity of fine particle nitrate ion volatilized from the Teflon filters; (b) Fine particle nitrate ion volatilized from Teflon filters as a percentage of the actual amount of fine particle nitrate present; (c) Fine particle mass concentrations measured on Teflon filters (black) showing the amount of fine particle mass lost from the samplers due to $\mathrm{NH}_{4} \mathrm{NO}_{3}$ volatilization.

the predominant cation found in the fine particle sulfate and nitrate salts in the Los Angeles area atmosphere.

The last row of graphs in Figures 5-7 depicts the concentration of crustal oxides measured at Long Beach, Central LosAngeles, and Rubidoux, respectively. Crustal oxides do not show any systematic seasonal variation over the course of the year, and the crustal oxide concentrations have remained relatively constant at individual sites over the years. In general, higher crustal oxide concentrations are observed as onemoves further inland from Long Beach toward Rubidoux. The climate at Rubidoux is hotter and drier than at the coast, leading to dustier conditions at that inland site.

Figure 9 shows the chemical composition of the air basin-wide maximum 24-hr average fine particle mass concentration event for each of the years studied. Table 2 gives the concentration and chemical composition of the sample with the highest 24-hr mass concentration taken at each air monitoring site shown in Figure 1. In 1982, the highest 24-hr average fine particle mass concentration occurred at Central Los Angeles and was found to be $166.4 \mathrm{\mu g} \mathrm{m}^{-3}$, while in both 1986 and 1993, the highest fine particle mass concentrations occurred at Rubidoux and were 242.6 and $139.2 \mu \mathrm{g} \mathrm{m}^{-3}$, respectively. The peak 24-hr average concentration at Rubidoux during 1982 also was within that range, amounting to $142 \mu \mathrm{g} \mathrm{m}^{-3}$, with substantial aerosol nitrate concentration, as shown in Table 2. Values shown in Figure 9 represent mass concentrations measured on Teflon filters and do not include correction for $\mathrm{NH}_{4} \mathrm{NO}_{3}$ lost by volatilization during sampling. For the 1986 sample, that nitrate volatilization loss was measured. The fine particle mass concentration measured at Rubidoux on October 29, 1986 would have been $263.2 \mu \mathrm{g} \mathrm{m}^{-3}$ after correction for $\mathrm{NH}_{4} \mathrm{NO}_{3}$ volatilization.

In general, it is seen that the highest fine particlemass concentrationsoccur during the cooler months of theyear, not in the middle of the summer photochemical smog season. Also, comparing the pie charts for the peak days in Figure 9 to the corresponding graphsshowing theyearly average chemical composition in Figure 4 , it is seen that aerosol nitrate concentrations are relatively higher under peak day conditions than on an average day. During 1986 and 1993, $\mathrm{NO}_{3}^{-}$and associated $\mathrm{NH}_{4}^{+}$accounted for the majority of the fine aerosol on the peak concentration days of the year. Thus it is clear that an accurate measurement of $\mathrm{NH}_{4} \mathrm{NO}_{3}$, including correction for volatilization losses, is necessary for an accurate measurement of peak 24-hr average and annual average fine particle mass concentrations in the Los Angeles area, and deliberate abatement of $\mathrm{NH}_{4} \mathrm{NO}_{3}$ concentrations will form a necessary component of any successful, major fine particle control program for the Los Angeles area.

\section{ACKNOWLEDGMENTS}

We would like to thank all those involved with establishing and maintaining the ambient particulate matter sampling networks, specifically Matt Fraser, Theresa Fall, and Andy Gray at the California Institute of Technology (Caltech) and Bill Bopeat theSouth Coast Air Quality Management District (SCAQMD). Theassistance of theU.S. Navy meteorological office at Pt. Mugu was critical to our ambient sampling activities on San Nicolas Island, and we 


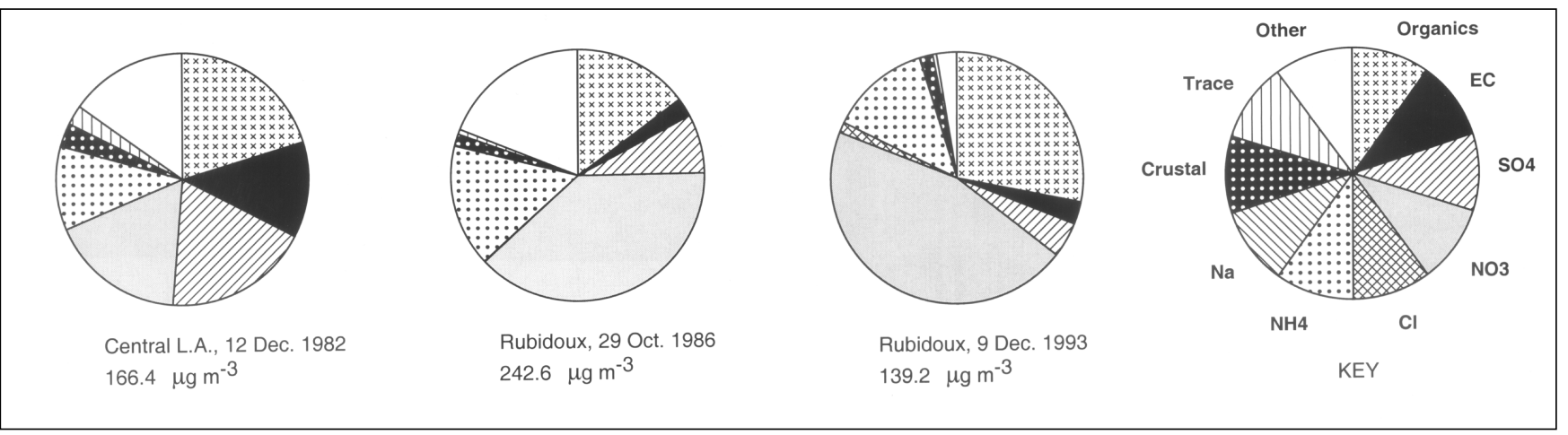

Figure 9. Fine particle chemical composition for the highest 24-hr average fine particle mass concentration value for the years 1982,1986 , and 1993. Values reported are for collection on Teflon filters. For magnitude of $\mathrm{NH}_{4} \mathrm{NO}_{3}$ volatilized from the Teflon filter during sampling in 1986 , see text and Figure 8.

especially thank Jay Rosenthal, Ken Fesperman, Carl Otten, Grady-Jim Roberts, and Lloyd Willet for help over theyears.

The analysis of data reported here was supported by program grant P01-ES07168 from the National Institute of Environmental Health Sciences and by the Caltech Center for Air Quality Analysis.

The previously unpublished 1986 fine particle measurement program was funded by the State of California Air Resources Board (Agreement No. A4-144-32). John Cooper at NEA Laboratories performed the 1986 analysis by XRF and Bob Cary of Sunset Laboratory, Forest Grove, OR, performed the 1986 analysis of organic and EC.

Collection of the 1993 samples was supported by the U.S. Environmental Protection Agency under grant R819714-01-0. Chemical analysis of the 1993 samples was supported by a research agreement with SCAQMD under Contract No. 96016. The 1993 OC and EC analyses were performed by Bob Cary at Sunset Laboratory. The XRF analyses contained in the final report to the SCAQMD were performed by the Desert Research Institute, Reno, NV, and special thanks go to Dr. Judith Chow and Cliff Frazier for their analysis of these samples.

\section{REFERENCES}

1. Middleton, W.E.K. Vision through the Atmosphere; University of Toronto Press: Toronto, Ontario, Canada, 1952.

2. National Research Council. Protecting Visibility in National Parksand Wilderness Areas; National Academy Press: Washington, DC, 1993.

3. Groblicki, P.J.; Wolff, G.T.; Countess, R.J. “Visibility reducing species in the Denver 'brown cloud'-relationships between extinction and chemical composition," Atmos. Environ. 1981, 15, 2473-2484.

4. Sloane, C.S.; Watson, J.; Chow, J.; Pritchett, L.; Richards, L.W. "Size segregated fine particle measurements by chemical-species and their impact on visibility impairment in Denver," Atmos. Environ. 1991, 25, 1013-1024.

5. Eldering, A.; Cass, G.R.; Moon, K.C. “An air monitoring network using continuous particle size distribution monitors: connecting pollutant properties to visibility via MIE scattering cal culations," Atmos. Environ. 1994, 28, 2733-2749.

6. Eldering, A.; Cass, G.R. "Source-oriented model for air pollutant ef fects on visibility," J. Geophys. Research 1996, 101, 19,343-19,369.

7. Dockery, D.W.; Pope, C.A., III; Xu, X.; Spengler, J.D.; Ware, J.H. Martha, E.F.; Ferris, B.G., Jr.; Speizer, F.E. "An association between air pollution and mortality in six U.S. cities," N. Engl. J. Med. 1993, 329, 1753-1759.
8. Pope, C.A., III; Thun, M.J.; Namboodiri, M.M.; Dockery, D.W.; Evans J.S.; Speizer, F.E.; Heath, C.W., Jr. "Particulate air pollution as a pre dictor of mortality in a prospective study of U.S. adults," Am. J. Respir. Crit. Care Med. 1995, 151, 669-674.

9. Pope, C.A., III; Dockery, D.W.; Schwartz, J. “Review of epidemiological evidence of health effects of particulate air pollution," Inhalation Toxicol. 1995, 7, 1-18.

10. Reichardt, T. "EPA considers standard for airborne fine particles," Environ. Sci. Technol. 1996, 30, A68-A69.

11. Gray, H.A.; Cass, G.R.; Huntzicker, J.J.; Heyerdahl, E.K.; Rau, J.A. “Characteristics of atmospheric organic and elemental carbon particle concentrations in Los Angeles," Environ. Sci. Technol. 1986, 20, 580-589.

12. Solomon, P.A.; Fall, T.; Salmon, L.G.; Lin, P.; Vasquez, F.; Cass, G.R. Acquisition of Acid Vapor and Aerosol Concentration Data for Use in Dry Deposition Studies in the South Coast Air Basin. Environmental Quality Laboratory Report 25, Final Report to the California Air Re sources Board under Agreement A4-144-32; California Institute of Technology: Pasadena, CA, 1988.

13. Wolff, G.T.; Ruthkosky, M.S.; Stroup, D.P.; Korsog, P.E. “A characterization of the principal $\mathrm{PM}_{10}$ species in Claremont (summer) and Long Beach (fall) during SCAQS," Atmos. Environ. 1991, 25, 2173-2186.

14. Kaplan, I.R.; Gordon, R.J. "Non-fossil fuel fine particle organic carbon aerosols in Southern California determined during the Los Angeles aerosol characterization and source apportionment study," Aerosol Sci. Technol. 1994, 21, 343-359.

15. Chow, J.C.; Watson, J.G.; Fujita, E.M.; Lu, Z.; Lawson, D.R.; Ashbaugh, L.L. "Temporal and spatial variations of $\mathrm{PM}_{2.5}$ and $\mathrm{PM}_{10}$ aerosol in the Southern California air quality study," Atmos. Environ. 1994, 28, 20612080.

16. Hannigan, M.P.; Cass, G.R.; Lafleur, A.L.; Busby, W.F., Jr.; Thilly, W.G. "Seasonal and spatial variation of the bacterial mutagenicity of fine organic aerosol in Southern California," Environ. Health Perspect. 1996, $104,428-436$.

17. John, W.; Reischl, G. “A cyclone for size-selective sampling of air," J. Air Pollut. Control Assoc. 1980, 30, 872-876.

18. Dzubay, T.G. X-ray Fluorescence Analysis of Environmental Samples; Ann Arbor Science: Ann Arbor, MI, 1977.

19. Huntzicker, J.J.; Johnson, R.L.; Shah, J.J.; Cary, R.A. Analysis of Organic and Elemental Carbon in Ambient Aerosols by a Thermal-Optical Method. In Particulate Carbon: Atmospheric Life Cycle; Wolff, G.T.; Klimisch, R.L., Eds. Plenum Press: New York, 1982.

20. Johnson, R.L.; Shah, J.J.; Cary, R.A.; Huntzicker, J.J. An Automated Thermal-Optical Method for the Analysis of Carbonaceous Aerosols. In Atmospheric Aerosols: Source/Air Quality Relationships; Macias, E.S. Hopke, P.K., Eds. American Chemical Society: Washington, DC, 1981.

21. Lin, C.; Baker, M.; Charlson, R.J. "Absorption coefficient of atmsopheric aerosol: a method for measurement," Appl. Optics 1973 12, 1356-1363.

22. Mueller, P.K.; Mendoza, B.V.; Collins, J.C.; Wilgus, E.A. Application of Ion Chromatography to the Analysis of Anions Extracted from Airborne Particulate Matter. In Ion Chromatographic Analysis of Environmental Pollutants; Sawicki, E.; Mulik, J.D.; Wittgenstein, E., Eds; Ann Arbor Science: Ann Arbor, MI, 1978; pp 77-86.

23. Solarzano, L. "Determination of ammonia in natural waters by the phenol-hypochlorite method," Limnol. Oceanogr. 1969, 14, 799-801.

24. Rogge, W.F.; Mazurek, M.A.; Hildemann, L.M.; Cass, G.R.; Simoneit, B.R.T. "Quantification of urban organic aerosols at a molecular level: identification, abundance, and seasonal variation," Atmos. Environ. 1993, 27, 1309-1330. 
25. Appel, B.R.; Wall, S.M.; Tokiwa, Y.; Haik, M. “Simultaneousnitric acid, particulate nitrate, and acidity measurements in ambient air," Atmos. Environ. 1980, 14, 549-554

26. Hering, S.V.; Lawson, D.R.; et al. "The nitric acid shootout: field comparison of measurement methods," Atmos. Environ. 1988, 22, 15191539.

27. Solomon, P.A.; Larson, S.M.; Fall, T.; Cass, G.R. “Basinwide nitric acid and related species concentrations observed during the Claremont Nitrogen Species Comparison Study," Atmos. Environ. 1988, 22, 1587 1594.

28. Solomon, P.A.; Salmon, L.G.; Fall, T.; Cass, G.R. "Spatial and temporal distribution of atmospheric nitric acid and particulate nitrate concentrations in the Los Angeles area," Environ. Sci. Technol. 1992, 26, 1594-1601.

29. Gundel, L.A.; Lee, V.C.; Mahanama, K.R.R.; Stevens, R.K.; Daisey, J.M. "Direct determination of the phase distributions of semi-volatile polycyclic aromatic hydrocarbons using annular denuders," Atmos. Environ. 1995, 29, 1719-1733.

30. Solomon, P.A.; Fall, T.; Salmon, L.G.; Cass, G.R.; Gray, H.A.; Davidson, A. "Chemical characteristics of PM ${ }_{10}$ aerosols collected in the Los Angeles area," J. Air Pollut. Control. Assoc. 1989, 39, 154-163.

31. Hannigan, M.P.; Cass, G.R.; Penman, B.W.; Crespi, C.L.; Lafleur, A.L.; Busby, W.F., Jr.; Thilly, W.G. "Human cell mutagens in Los Angeles air," Environ. Sci. Technol. 1997, 31, 438-447.

32. Hannigan, M.P.; Salmon, L.G.; Christoforou, C.S.; Gharib, S.S. Butcher, C.H.; Cass, G.R.; Chow, J.C.; Frazier, C.A. Determination of Fine ParticleConcentration and Chemical Composition in the South Coast Air Basin, 1993. Final Report to the South Coast Air Quality Management District; California Institute of Technology: Pasadena, CA, 1996.

33. Cass, G.R.; Gray, H.A. Regional Emissions and Atmospheric Concentrations of Diesel Engine Particulate Matter: Los Angeles as a Case Study. In Diesel Exhaust: A Critical Analysis of Emissions, Exposure, and Health Effects; Health Effects Institute: Cambridge, MA, 1995.

34. Schauer, J.J.; Rogge, W.F., Hildemann, L.M.; Mazurek, M.A.; Cass, G.R.; Simoneit, B.R.T. "Source apportionment of airborne particulate matter using organic compounds as tracers," Atmos. Environ. 1996, 30, 3837-3855.

35. Gray, H.A.; Cass, G.R. "Source contributions to atmospheric fine carbon particle concentrations," Atmos. Environ. 1998, 32, 3805-3825.

36. Sawyer, R.F.; Johnson, J.H. Diesel Emissions and Control Technology. In Diesel Exhaust: A Critical Analysis of Emissions, Exposure, and $\mathrm{Health}$ Effects, Health Effects Institute, Cambridge, MA, 1995.

37. Pierson, W.R.; Brachaczek, W.W. "Particulate matter associated with vehicles on the road. II," Aerosol Sci. Technol. 1983, 2, 1-40.

38. Gertler, A.W.; Wittorff, D.N.; Zielinska, B.; Chow, J.C. Determination of Mobile Source Particulate Emission Factors in Tunnels. In Proceedings of the A\&W MA International Specialty Conference-Particulate Matter: Health and Regulatory Issues; Air and Waste Management Association, Pittsburgh, PA, 1995.

39. Hildemann, L.M.; Markowski, G.R.; Cass, G.R. "Chemical composition of emissions from urban sources of fine organic aerosol," Environ. Sci. Technol. 1991, 25, 744-759.

40. Hildemann, L.M.; Cass, G.R.; Mazurek, M.A.; Simoneit, B.R.T. “Mathematical modeling of urban organic aerosol-properties measured by high-resolution gas-chromatography," Environ. Sci. Technol. 1993, 27, 2045-2055.

41. Gray, H.A. Control of Atmospheric Fine Primary Carbon ParticleConcentrations; Ph.D. Thesis, California Institute of Technology, Pasadena, CA, 1986

42. South Coast Air Quality Management District. 1997 Air Quality Management Plan, Appendix III, Attachment C; South Coast Air Quality Management District: Diamond Bar, CA, 1996.

43. Cass, G.R. "Sulfate air quality control strategy design," Atmos. Environ. 1981, 15, 1227-1249.

44. Cass, G.R. Methods for Sulfate Air Quality Management with Applications to Los Angeles; Ph.D. Thesis, California Institute of Technology, Pasadena, CA, 1978.
45. South Coast Air Quality Management District. Sulfur Dioxide/Sulfate Control Study-Main Text; South Coast Air Quality Management District: El Monte, CA, 1978

46. South Coast Air Quality Management District. 1994 Air Quality Management Plan; South Coast Air Quality Management District: Diamond Bar, CA, 1994.

47. Russell, A.G.; Cass, G.R. "Verification of a mathematical model for aerosol nitrate and nitric acid formation and its use for control measure evaluation," Atmos. Environ. 1986, 20, 2011-2025.

48. Russell, A.G.; McCue, K.F.; Cass, G.R. "Mathematical modeling of the formation of nitrogen-containing air pollutants. 1. Evaluation of an Eulerian photochemical model," Environ. Sci. Technol. 1988, 22, 263 270.

49. Russell, A.G.; McCue, K.F.; Cass, G.R. “Mathematical modeling of the formation of nitrogen-containing air pollutants. 2. Evaluation of the effect of emission controls," Environ. Sci. Technol. 1988, 22, 13361347.

50. Appel, B.R.; Tokiwa, Y.; Haik, M. “Sampling of nitrates in ambient air," Atmos. Environ. 1981, 15, 283-289.

51. Forrest, J.; Spandau, D.J.; Tanner, R.L.; Newman, L. “Determination of atmospheric nitrate and nitric acid employing a diffusion denuder with a filter pack," Atmos. Environ. 1982, 16, 1473-1485.

\section{About the Authors}

Christos $\mathrm{S}$. Christoforou is an assistant professor in the environmental engineering program at Clemson University. Lynn G. Salmon is a research engineer at the California Institute of Technology. Michael P. Hannigan is a research assistant professor at the University of Denver. Paul A. Solomon is with the Office of Research and Development, U.S. Environmental Protection Agency, MD-46, Research Triangle Park, NC 27711. At the time of this work, Glen R. Cass was a professor of environmental engineering and mechanical engineering at the California Institute of Technology. His present address is School of Earth and Atmospheric Sciences, Georgia Institute of Technology, Atlanta, GA. 